\title{
50 Teachings of Household Harmony at "Upacara Panggih" Javanese Style Bridal Ceremony in Yogyakarta
}

\author{
S Dwijonagoro ${ }^{1}$, E Istikomah ${ }^{2}$ \\ \{1 suwarnadr@uny.ac.id, ${ }^{2}$ erna.istikomah@uny.ac.id $\}$ \\ ${ }^{1,2}$ Universitas Negeri Yogyakarta, Indonesia
}

\begin{abstract}
Household harmony is the desire of all married couples. Harmony brings peace of life in the family so that the household lasts until the end of life. Early marriage harmony was taught in the Javanese bridal summoning ceremony. This naturalistic qualitative study was carried out to uncover the doctrine of marital harmony in 40 Yogyakarta Javanese bridal wedding ceremonies. Obtaining data is done by participant observation and in-depth interviews. The validity of the data by triangulation, sharpened by extended participation and repeated studies. Data analysis uses the tradition of Miles, Huberman, \& Saldana (2014). The doctrine of family harmony in the summon ceremony is found in the ceremonial procedures and procedures. The ceremonial procedure is related to the act in the ceremonial summon, while the procedure is related to the equipment / tools used in the summon ceremony. The teachings of harmony can be grouped into (1) parental responsibilities, (2) mate selection, (3) happiness in the family, (4) husband's and wife's obligations, (5) filial piety, and (6) loving/ be generous to others by giving alms.
\end{abstract}

Keywords: Harmony, Household, Panggih

\section{INTRODUCTION}

Sophisticated bridal is a wedding gathering ceremony in the Javanese bridal tradition [1]. This summon ceremony will continue to be sustained during the Javanese bridal ceremony. The preservation of the bride wedding ceremony is based on several arguments (1) as long as there are Javanese people, there is a wedding ceremony. As long as there are Javanese traditional wedding ceremonies, the summoning ceremony is still held, (2) the summoning ceremony is local wisdom or local genius, (3) the summoning ceremony contains a lot of aesthetics, (4) the summoning ceremony is the core of the Javanese wedding ceremonies, (5) Cheap summoning ceremonies are held, there is no need to add property significantly. In general, the summoning ceremony is already a bridal makeup package, (6) the summoning ceremony has a beautiful teaching load (cultural semantics) in the household.

In the City of Yogyakarta and its surroundings there are at least 76 wedding ceremonial venues (conference halls, auditoriums, hotels, restaurants, village halls). Of the 76 bridal meeting halls there are 39 locations that are active each week [2]. Each Building averages 2-4 times a week. If taken median, each building holds a bridal ceremony 3 times / week. Of the 3 times a week 1 that does not hold a summoning ceremony. This means that there are $66.67 \%$ of the bridal ceremony held a summon ceremony every week. 
Panggih ceremony is a local wisdom or local genius for Javanese people. As a local wisdom, the Javanese bride has a special ceremony that distinguishes it from other ethnic bridal ceremonies. This local wisdom or genius is still held in high esteem by the Javanese. As a form of appreciation for the noble work of Javanese ancestors, the summon ceremony was still held because the summon ceremony had symbolic meaning [1], [3]. Symbolic meaning can be used as teachings in building new households. If the teachings are lived and carried out, domestic harmony can be achieved.

Panggih ceremonies also contain a lot of aesthetics, namely visual aesthetics, lingual, and auditory aesthetics. Visual aesthetics appear from cosmetology and fashion which are full of teachings. Lingual aesthetics are beautiful utterances from pranatacara (master of ceremonies) to describe and interpret the ceremony call (panyandra). Pranatacara uses literary language (beautiful language). The beauty of auditors is the beauty of hearing. The beauty of hearing is the beauty of the speech utterances and musical accompaniment in harmony. All of that is the poliharmony (harmony of many elements) of the speech rhythm of the pranatacara, the song that is sung by the 'woman singer' waranggana and accompanying music.

The summoning ceremony has a beautiful teaching content for married life. The teaching is intended by a pair of brides who form a new family to be sustainable, full of love and happy.

\section{RESEARCH METHOD}

This research includes qualitative research [4]. The study was conducted in the City and Sleman regions of the Special Region of Yogyakarta and in 2018 every week a Javanese-style Javanese bridal wedding ceremony was held. Within a year minus the month of Sura and Ramadan there were 40 Javanese bridal wedding ceremony ceremonies. Data acquisition techniques by observation and in-depth interviews. There are two types of observations used, namely non-participant direct observation and participant direct observation. Direct observation by means of 1 or 2 researchers observed the bridal ceremony directly when the Javanese bridal wedding ceremony called Yogyakarta. Direct participant observation in which 1 other researcher becomes part of the wedding ceremony, which is to become a lawyer (pranatacara). The speakers are the master of ceremonies. The research instruments used were observation sheets, interview guides, audio and video recordings, and photography. The validity of the data is obtained by (1) in-depth observation, (2) quantity of participation, (3) triangulation of sources, and (4) data saturation [5]. Research analysis using the model of Miles, Huberman, \& Saldana [6] with the steps of exploration, description, data compilation, elaboration, prediction, elaboration, and inference.

\section{RESULTS AND DISCUSSION}

The results of research on the doctrine of harmony in marriage at the Javanese bridal wedding ceremony ceremony style of Yogyakarta can be seen in Table 1. The teachings of harmony in a number of stairs are contained in the ceremonial and procedural procedures. The ceremony was related to the event which was held at the Javanese bridal wedding ceremony. Procedures related to tools or used in Panggih Ceremony. 
Table 1. The teachings of the household in the Yogyakarta Javanese bridal wedding ceremonies

\begin{tabular}{|c|c|c|c|}
\hline No. & Teachings & ceremony & Order system \\
\hline 1. & Parental responsibility & & Pisang sanggan \\
\hline 2. & Arranged marriage & & $\begin{array}{l}\text { Suruh ayu } \\
\text { Gantal }\end{array}$ \\
\hline 3. & Family happiness & & Gedang aуu \\
\hline 4. & Holy intention & & Kembar mayang \\
\hline 5. & Sweet household life & & Pisang raja \\
\hline 6. & Eternal marriage & & $\begin{array}{l}\text { Kembar } \\
\text { mayang/kalpataru }\end{array}$ \\
\hline 7. & Strength of marriage & & $\begin{array}{l}\text { Root of bayu bajra } \\
\text { kembar mayang }\end{array}$ \\
\hline 8. & Love as a basis for marriage & & Kayu purwo sejati \\
\hline 9. & Traveling safety & & Keblat papat \\
\hline 10. & Protect the family & & Pradapa mega rumembe \\
\hline 11. & A gift of kindness in the family & & Daru \\
\hline 12 & Family fame & & Kilat \\
\hline 13. & Cast away the pesky family & Gepyokan kembar mayang & \\
\hline 14. & If borrowing, must return & & $\begin{array}{l}\text { Get rid of kembar } \\
\text { mayang }\end{array}$ \\
\hline 15. & $\begin{array}{l}\text { The husband is a source of } \\
\text { enlightenment for the wife }\end{array}$ & & Gantal gondhang tutur \\
\hline 16. & Wife loves husband & & Gantal gondhang kasih \\
\hline 17. & $\begin{array}{l}\text { Legitimate ties in family/ } \\
\text { marriage }\end{array}$ & & $\begin{array}{l}\text { Tali wenang putih pada } \\
\text { gantal }\end{array}$ \\
\hline 18. & Wife leader husband & $\begin{array}{l}\text { The bride and groom start the } \\
\text { throw gantal. }\end{array}$ & \\
\hline 19. & Balance husband's wife & $\begin{array}{l}\text { The bride following throws } \\
\text { gantal }\end{array}$ & \\
\hline 20. & Balance between logic and feeling & $\begin{array}{l}\text { The grom throw gantal on the } \\
\text { Bride's forehead, while the } \\
\text { Bride throws a chew on the } \\
\text { groom's chest. }\end{array}$ & \\
\hline 21. & Husband as a wife protector & $\begin{array}{l}\text { Bride chant throwing on the } \\
\text { groom knee (jengku). }\end{array}$ & \\
\hline 22. & $\begin{array}{l}\text { The balance of creativity, taste, } \\
\text { and intention }\end{array}$ & $\begin{array}{l}\text { Throw gantal on the forehead, } \\
\text { chest, and knees / feet }\end{array}$ & \\
\hline 23. & Wives serve their husbands & Radupada & \\
\hline 24. & Hope beautiful household & & Kembang setaman \\
\hline 25 & $\begin{array}{l}\text { The hope of a cool household is } \\
\text { based on purity of heart }\end{array}$ & & Perwitasari's water \\
\hline 26. & Hope is given offspring & break antiga & Antiga \\
\hline 27. & Togetherness in the family & Kirab & \\
\hline 28. & Parents provide support & $\begin{array}{l}\text { Parents follow the bride behind } \\
\text { the bride. }\end{array}$ & \\
\hline 29. & $\begin{array}{l}\text { The teaching of mutual } \\
\text { cooperation }\end{array}$ & $\begin{array}{l}\text { Kirab pengantin } \\
\text { Arrangement of carnival }\end{array}$ & \\
\hline
\end{tabular}


30. Men respect women

$31 \quad$ Be a responsible parent

32. Make generous don't be stingy / charitable

33. Fair / not favoritism

34. The husband is responsible for the life needs of his wife / family

35. Families need food and clothing

36. Family Glory

37. Family life requires funds / wealth

38. Nothing is big without starting small

39 Women / wives are always happy to accept gifts from their husbands

40. Be a wife who can take care of the husband's fortune

41. Dutiful to parents

42. Determination is united forever

43. Build a family with determination

44. The wife obeys the husband

45. Think and act based on a clear heart

46. Appreciate and respect in-laws

47. Forgiving

48. Parents support the blessing of children

49. Parents love their children and grandchildren

50. Families/ living people need to be healthy mothers first, then fathers who

in laws

Bubak kawah

Bubak kawah Mother feeds her husband and bride

Giving rujak with evenness is not favoritism

Groom gives tampa kaya

Rice and beans, corn

Yellow rice

Yellow rice on dhahar

walimah

money

small change

the bride accepts tampa kaya

the bride accepts tampa kaya

Pisungung tampa kaya

Sungkeman

The groom fists yellow rice

bride and groom enjoy dhahar

walimah

drinking clear water clear water

pick up in-law

Sungkeman parents forgive the bridegroom's mistake

Sungkeman

Tumplak punjen
Pindhang ati antep

Empon-empon

\section{Parental responsibilities}

A harmonious family has parents who are responsible for domestic life. The responsibility in the summoning ceremony is that parents are ready to finance the marriage of their children as in Javanese proverbs, the father's father said that all children's wishes are the responsibility of parents (in terms of cost). The value of responsibility in the harmony of the household is symbolized by the surrender of the bananas from the bridegroom (the mother of the male supervisor) to the woman (the bride's mother). 


\section{An arranged marriage}

Arranged marriages are symbolized by the ayu 'betel leaf'. In Javanese culture the betel Dauh is a symbol of matchmaking. Tell the opponent's house kurepe to be different with a single gasan rupet rasane iri betel leaf is different between the top and bottom surfaces, but when bitten the same taste. Likewise, men and women (bride) are of different sex, but when they become brides, they are one, that is, a new family.

\section{Family happiness}

The hope of a happy family is symbolized by the gedhang ayu den gadang inflamed rahayu "plantain which is a symbol of happiness or family safety. Sanggan bananas are selected plantains that have been cooked one Tangkep ( 2 combs). Plantain has a taste. Sweet and durable. It is hoped that the family formed will be happy forever.

\section{Sacred intention}

The teachings of sacred intentions in arranged marriages are symbolized in the form of white lawe wrapped around plantains. White lawe is a spun endless tulip yarn. White lawe is a symbol of sacred intention. Lawe who has no fighting and stems shows sacred intentions forever (no end).

\section{Sweet family life}

The teachings of sweet and durable family life (lestrai) are symbolized in plantains. Plantain is a banana that tastes sweet and durable (not easy to rot). This means that plantain is the hope of sweet and unified household life forever.

\section{Eternal Housekeeping}

What is meant by eternal marriage is that the husband and wife remain united (not divorced) until the end of life. The immortality of the household is symbolized in the form of twin mayangs, also called kalpataru. The name Kalpataru as an environmental preservation gift is taken from the mayang twin kalpataru. With the symbol of the Kalpataru (kalpa: eternity, taru: tree), it is hoped that the bride will not be separated forever until the end of her life.

\section{Strength of marriage}

The summoning ceremony uses Mayang twins as a means of calling. In the cultural treasures of the Mayang twin wedding ceremony, it is also called Kalpataru, Jayadaru, Klepu Dewa Daru wood. Mayang twins have elements of roots, stems, branches, leaves, flowers, and fruit. Mayang twins have roots called bayu bajra or strength. This means that the family remains strong despite the wind of trials. There is no family without trials. But trials are overcome with strength or unity that remains united so that every problem can be solved.

\section{Love as a basis for marriage}

Mayang twin stems are called true purwa wood 'that being a bride is the origin of starting a new life, namely the life of building a household mahligai. Building a house is based on love. The union of men and women in the family because of or begins with a sense of love. 


\section{Traveling safety}

Household harmony can also be enjoyed when the family always finds harmony in all its activities. Family safety is symbolized in the branch of the Mayang twin tree, the papat keblat papat 'four corners of the Qibla.' In family life, the family must travel. Wherever they go (keblat papat) is expected to always meet safety.

\section{Protect the family}

The bride can be a protector in her family (her sons and daughters tomorrow). This protection is symbolized in twin mayang leaves called the pradapa mega rumembe. Mayang twin leaves are likened to a very dense can be a place of "shelter" for anyone. This means that brides can provide protection. Protection or protection can be broadly meaningful, the husband nurtures his wife, the wife nurtures his sons and daughters, or even in guardian twins may mean that the family can protect other family members and protectors in social life.

\section{The gift of kindness in the family}

The gift in the family is symbolized in the flower of the twin mayang tree (kalpataru). The virtue in the twin twins is symbolized by the flowers. The flower of the twin mayang tree is daru. In JavaneseV culture, daru is a gift of kindness. Mayang twins are also called dewadaru. It means the gift of kindness from Almighty God.

\section{Family fame}

The fame of the family is symbolized by lightning twin mayang fruit. Light emits light. Light is a symbol of fame. This flash can be seen by others. The meaning of the family can be known public (famous / famous). Fame can be achieved if the family achievers. Achievement can refer to the best achievements of various things (success, happiness, generosity, position, rank, position, goodness / nobility, and so on).

\section{Throw out the bad luck of the family}

Throwing the afternoon out in the family is symbolized by the Mayan Twin Ryokan. At the mayang twin summon ceremony brought by the mothers touched on the right and left shoulder of the groom. After the twin twins are touched on the groom's right and left shoulder, the twin twins are thrown to the crossroad or to the river (anchored). In this way, the family is expected to avoid bad luck so that it always finds safety.

\section{If borrowing must return}

In the story, Mayang twins are loans from the gods to haja holders. When the intentions are over, the Mayang twins must be returned by floating (dumping) in the middle of a crossroad or in a river. The crossroad is a symbol of the four directions (four directions of the wind). After being returned, the Mayang twins will return to their origin through the four cardinal points. Mayang twins returned through the river are a symbol of bad luck. The implications of this teaching are general loans including debt. The debt must be paid off.

\section{Throw out the bad luck of the family}

Throwing the afternoon out in the family is symbolized by the Mayan Twin Ryokan. At the mayang twin summon ceremony brought by the mothers touched on the right and left 
shoulder of the groom. After the twin twins are touched on the groom's right and left shoulder, the twin twins are thrown to the crossroad or to the river (anchored). In this way, the family is expected to avoid bad luck so that it always finds safety.

\section{Husband becomes a source of enlightenment for his wife}

The husband's teaching is a source of enlightenment for the wife symbolized by the four pieces held by the bridegroom at the summoning ceremony. Gantal is betel leaf tied with white thread. The gantal of the groom is called the gondang utur. This means that the bridegroom can advise the bride. To be able to become an enlightenment and source of advice for wives, the husband must be rich in knowledge or insight. An intelligent and insightful husband who is wise can surely be a guide and advisor to his wife.

\section{Wife loves husband}

The wife loves her husband symbolically in the three pieces held by the bride. The bride's bride is called the love gondhang. This means that women have love for their husbands. With the power of love, the wife obeys to the husband. Husbands who can guide their wives and wives who love their husbands make a harmonious family.

\section{Legitimate ties in family / marriage}

A legal bond in a family or marriage is symbolized in a white string that ties a cushion. Gantal tied with white thread is a symbol of men and women who are bound by a legal bond, namely marriage / marriage. White is a symbol of purity. Marriage should be based on a pure intention and heart.

\section{Wife balancing husband}

The wife is ready to be a partner, partner or husband balance. During the summoning ceremony, the bridegroom starts throwing the gantal and the bride replies. It symbolizes action and reaction, stimulus response, husband and wife balance. The bride throws the paddle 3 times to the bridegroom with one by one alternating throwing the thump. Throw the bridegroom off the pitch 4 times. Hunger also one by one.

\section{Balance between logic and feeling}

At the bouncer spinning ceremony, the first bounce of the bridegroom is attempted right on the bride's forehead. Whereas the first lock for the bride is right on the groom's chest. The bride's bouncy kick right on the bride's forehead means that the bride empowers logic. Instinctively, in dealing with a case a strong woman / prioritizes her feelings and prioritizes logic. That is why if there is a problem, women tend to be sad or cry first and then think of a solution. Therefore, in order to strike a balance between feelings and logic, the bride's first toss hit the bride's forehead. The first thrum of the bride on the bride's groom. In contrast to women, a man is stronger / puts logic first and prioritizes his feelings. Sometimes it happens in an affair for a man 'hit the back affair first'. That is why sometimes men are too rushed in dealing with problem solutions.

In this condition, the ancestors of the Javanese culture local wisdom experts (especially the bridal summoning ceremony) have made a symbolic act with wisdom, namely the bride's first throwing pad right on the bride's forehead. While the first throwing of the bride right on the groom's chest. 


\section{Husband as wife protector}

The bridegroom's two thumps hit the bride's chest with a meaning that evokes compassion. Whereas the 3rd and 4th throws to the bride's knee. The bride's 2nd and 3rd throwing pitches also point to the knee. Knee in Javanese krama jengku which means ngajeng-ajeng ing pamengku (folk etymology). It means to hope to be guided and protected. The bride and groom respect each other, respect, guide, and protect.

\section{The balance of creativity, taste, and intention}

The bouncy or betel nut between the bride and groom also symbolizes the balance of creativity, taste, and intention. Throwing the bride's forehead is copyright, the throwing the bride's chest and the bride is a symbol of taste, the throwing the bride's knee and the bride is the symbol of the quartz. So the throwing is an expectation of a balance of creativity, taste, and intention. The balance of creativity, taste, and intention is also taught by Ki Hajar Dewantara (2013).

\section{Wives serve their husbands}

The teachings of a devoted wife to a husband are symbolized at a ranupada event. Ranu means water, on means feet. Radupada means the bride washing the bridegroom's feet. Washing is a sign of the devotion of a wife to her husband. How to wash the bridegroom's feet, the bride by worshiping first. The bride then rests and wash the feet of the bridegroom. The devotion of a wife is also strengthened by the bride's worship of the bridegroom.

\section{Beautiful household expectations}

The hope of a beautiful household is symbolized in the three that are used for ranupada (washing the bridegroom's feet). All three are roses, jasmine, and memories. These three flowers were chosen for Javanese people in particular and Indonesians in general. However, in the etymology of the people (kerata basasa) the three flowers above also contain the meaning of what kang binawar is so lathi that I can remember remembering. This means that the advice given by the bridegroom will be remembered in the heart (and carried out). The three flowers scattered the scent of fragrance as a sign of life expectancy the bride will smell. It means giving goodness to others so that his life will be remembered.

\section{A cool household based on purity of heart}

This teaching is symbolized by the territorial water. Perwita means holy. Sari means flower. Perwitasari water is holy water combined with three rose flowers, jasmine and cananga. These three are called telon flowers (three flowers) or sekar tricolor (three kinds of flowers). Perwitasari water is used to conduct ranupada 'wash the bridegroom's feet by the bride'. Ranupada as a sign of the devotion of a wife to her husband is based on a pure intention or purity of heart.

\section{Hope is given offspring}

Heredity is one of the goals of building a household. Heredity is also one of the supporters of harmony in domestic life. That is why husband and wife who have not been blessed with offspring (children) try in various ways to be given offspring by God Almighty. The hope of the descendants in the summon ceremony is symbolized. 


\section{Togetherness in the family}

Togetherness in the family goes hand in hand in rhythm, friends when happy, and friends when mourning is symbolized in the bridal ward. Kirab is the bride's journey accompanied by both parents / married, siblings, and relatives to the altar. This Kirab is rhythmic, runs in an orderly manner, and the rows are also regulated in how to dress, the height of the participants is high, the accompaniment of gending is so beautiful and sounds grand.

\section{Parents provide support}

In the bridal hall, the parents of the bride and groom walk along with the bride and groom. As in the Javanese proverb, it invites sung tuladha, while middle builds karsa, tutwuri handayani 'in front gives an example, in the middle motivates, and at the end provides support. Because their children have become brides or built households, parents only need to support from behind. Parents should not interfere in their children's household affairs. Instead the child must be ready to be independent no longer depends on the parents.

\section{The teaching of mutual cooperation}

This teaching is found in the bridal hall. The bride and groom are supported by parents, siblings, and all extended families or relatives. This shows the attitude of mutual support or mutual cooperation. Conversely as a bride, the selection of a mate also needs to consider the consent of parents, siblings, extended family, and relatives. Thus all support each other. Its existence is mutual cooperation in the family.

\section{Men respect women}

The doctrine that men must respect women is found in the composition of the bridal hall. Parents follow the wedding journey of the bride (the king one day). The composition, mothers (the mother of the bride and groom stand before the fathers (father)), this means that a man must respect women especially his mother.

\section{Be a responsible parent}

This teaching is found in the crater bubak event. Bubak crater is a special event in the summoning ceremony. Crater Powder was held at the first in-law event (Kakung, 1988). The trick is, the bride's mother gives rujak degan drink to her husband. Next the bride's parents give rujak degan drink to the bride. The doctrine of responsibility lies with the daughter-inlaw. A daughter-in-law's ceremony costs money, especially if a daughter-in-law's reception is held at the conference hall by inviting a large number of guests.

\section{Be generous, don't be stingy}

This teaching is found in the crater bubak event when the bride's parents give rujak degan drink to the bride and groom. Even giving it by being bribed. It means to give sincerely with love. This teaching is also found in the punjen tumplak (last in-law ceremony). In the public transportation center, the stakeholders spread the udhik-udhik as a symbol of giving to others.

Like giving or giving alms taught by parents in the event distribution of udhik-udhik. Spreading udhik-udhik derived from the tradition of the palace. At certain ceremonies (such as grebeg, punjeng bridal ceremonies) the king spreads udhik-udhik which contains yellow rice, 
beans, empon-empon, and coins. The court's custom was imitated by the people at a public gathering. The bride is king one day. So people spread udhik-udhik to give examples of charity (hard to give).

\section{Fair / not favoritism}

In giving alms, the bride's mother is fair, not favoritism. Rujak bribes can be given to anyone, namely father / husband, bridegroom, and bride. This equal and equal gift shows fairness in the family. In spreading undhik-udhik, parents do not choose whoever is fighting for blessing (hoping for fortune blessing). Children, grandchildren, and all guests may fight over the lakes. Likewise, sohibul intrigued in throwing udhik-udhik not to a certain point. Udhik-udhik were distributed in all directions of the crowd so that everyone present could receive blessings.

This means that the advice given by the bridegroom will be remembered in the heart (and carried out). The three flowers scattered the scent of fragrance as a sign of life expectancy the bride will smell.

\section{The husband is responsible for family needs}

Husbands have an obligation to make ends meet in the family. The husband is in charge of earning a living. This is symbolized as a non-rich event. The groom gives riches (in the form of beans, corn, yellow rice, and coins) to the bride. Giving rich is a teaching that the husband is obliged to meet the needs of life in the family. Nuts, corn and yellow rice are symbols of food and clothing generosity. Small change is a symbol of wealth. The dime symbolizes nothing big without beginning with a small one.

\section{Families need food and clothing}

Rich Tampa consists of beans, corn, yellow rice, and money. Nuts, corn and rice are symbols of basic needs, namely food and clothing. The husband works hard to make ends meet for the family. This teaching is found in the tampa rich event (symbol of giving a living from the bridegroom to the bride). That families need food and clothing is also available at the public transportation gathering event. Punjen tumpplak is a Javanese tradition event that was held during the last mangu summoning ceremony. All children and grandchildren sungkem to parents (stakeholders). After the process of children and grandchildren are given kimp-kampil which contains yellow rice, beans, empon-empon, and money (can also be given other prizes such as the distribution of inheritance (of course agreed upon previously), gift giving home, car, and so on.

\section{Family glory}

The glory of the family is symbolized by the yellow color of rice. According to the belief of the yellow Javanese is a symbol of glory. The yellow symbol of glory also occurred during the March 1, 1949 General Offensive in Yogyakarta. All soldiers tied their heads with yellow leaves. In the Ramayana story, Sugriwa also wears a yellow leaf marker. At the time of the Eruption Reaching 2010, Mbah Marijan also appealed to its citizens to plant a yellow leaf above the main door of the house (the front entrance to the house). Tingkeban also used colorful letrek. Yellow as a symbol of glory. The teachings of glory aside from being in the event of how rich, there is also a punjen gathering event. The skills given by parents to posterity include yellow rice. Yellow is the color that symbolizes the ideals of glory. 


\section{Family life requires funds / wealth}

The need for funds in the family is symbolized in the form of small change without wealth. Money is a symbol of the need for funds. Funds are used for spending to meet the needs of life in the family. To make ends meet, families need wealth (money). People who work also find money to get a salary. The salary is for the wife. The wife governs the family economy. This teaching is found in ppleng tumplak. Parents give skills to their children and grandchildren. Kampil-kalmpil contains, among others, money which is a symbol of the need for property. With the hope that his children and grandchildren will have sufficient assets. Even better if your children and grandchildren can be rich. If your children and grandchildren are rich, don't forget to give alms.

\section{Nothing is big without starting small}

A dime in the rich without a symbol that there is no big without starting small. It was like proverbs Gradually gradually became a hill.

\section{Women/wives are always happy to accept gifts from their husbands}

Tampa is richly accepted by brides with approval. Whatever is given by the husband will be accepted sincerely and cheerfully. It is very possible that family income is not stable, sometimes a lot, sometimes a little. But as a dutiful wife, accepting gifts from her husband with a sincere heart.

\section{Be a wife who can take care of the husband's fortune}

This teaching is found in the rich without the wife receiving the husband's gift with none of the rich without spilling. This is a sign that the bride will be a wife who is passionate, nastiti, surti, lan-ati appreciates fortune, conscientious, frugal, and careful.

\section{Filial to parents}

The devotion of children to parents is shown at offerings without wealth and friendship. After the bride receives wealth / fortune from the bridegroom, the bride also presents a fortune. It should be true that as a child he must offer some of the fortune to his parents. Parents who have educated, raised, and matured with a stream of sweat and love tiara boundaries.

The devotion of children to parents is also shown by the sungkem event or the worship of the bride and groom to her parents. The contents of devotions are to apologize, say thank you for the parents' kindness, and the bride's blessing to the parents. Worship is also a symbol that the bride upholds, respects, respects and obeys parents.

\section{Determination of creativity, taste and intention}

Before enjoying a dish called dhahar klimah or dhahar walimah, the bridegroom fists yellow rice. With the determination to unite the heart, family, and love, yellow rice is clenched into the hands of the bridegroom's hands. While balling, yellow rice was determined in the heart to blend the creativity, taste, and intention. Husband and wife who are compact so that hope is reached that the bride and groom will be united forever. 


\section{Build a family with determination}

This teaching is symbolized by the antep pindhang which is a side dish of yellow rice. Pindhang ati antep is chicken liver cooked by steaming. Pindhang ati antep as a symbol of the stability of a married wife of his own choice.

\section{Wives obey their husbands}

The wife obeys to the husband is symbolized in the Dhahar Klimah. The bride eats yellow rice from the groom's head. This means that the bride is obedient to the husband's words (advice, commands, suggestions, criticism, proposals, discussion). The results of the head of rice (husband's command) are enjoyed (obeyed) by the wife (bride).

\section{Think and act based on a clean heart}

Drinking clear water after eating yellow rice is a symbol that everything is said and the attitude will be based on a clear heart. The silence of the heart will be expressed in actions and words that always make people happy "for their kindness," as said by Wong Agung ing Ngeksiganda Panembahan Senapati on the Sinom song which is very familiar and popular to the Javanese people. The song is found in the book Wedhatama by KGPAA Mangkunegara IV (Sing, 1956). The song is:
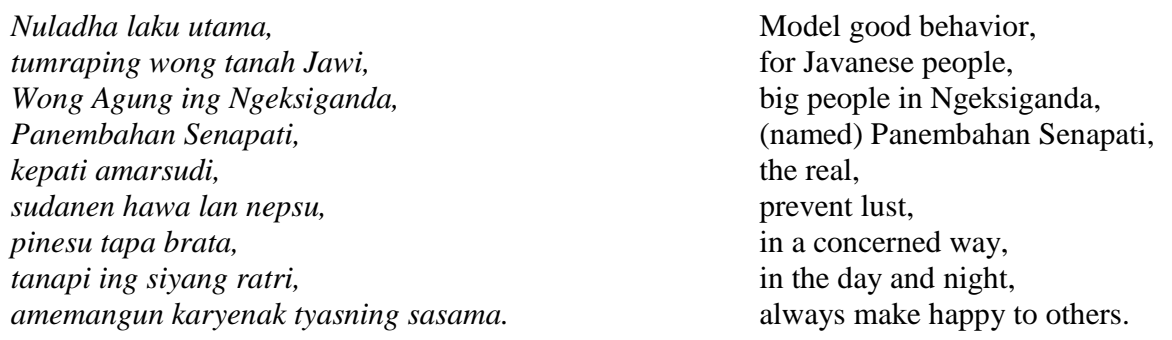

\section{Appreciate and respect in-laws}

Appreciating and respecting in-laws (the groom's parents) is symbolized by the in-law mapag event. The commander of the bride (the bride's parents) came down from the aisle to welcome the in-law presence. After shaking hands, in-laws are delivered until they sit on the side of the bride's seat. If expanded, the attitude of respect and respect not only to in-laws, but to fellow humans (especially in-laws).

\section{Forgiving}

Family harmony can also be created when family members (husband-wife-children) have a forgiving spirit. Forgiveness will create a harmonious situation, an open heart, a peaceful atmosphere. Being forgiving is not easy. It's easier for people to apologize than to forgive. But forgiving (being forgiving) is more noble than apologizing. Being forgiving has been exemplified by parents to their children at sungkeman or worship services. 
At the Sungkeman parents give their prayers and blessings on the marriage of their children or bride. Prayer for blessing to happiness, prosperity, glory, for the bride to be eternally inseparable. Only lives that escape the body that can separate the two.

\section{Loving children and grandchildren}

This teaching is found in the punjen gathering event. As a realization of that affection. After all the children and grandchildren Sungkem, they were given a skillful side with yellow rice, empon-empon, and money (or other gifts). That's the love of parents is like all the way.

\section{Living people need to be healthy}

The doctrine of health in the family is symbolized by empon-empon found in the skills of giving parents to their children and grandchildren. Empon-empon is a symbol of health. Empon-empon is a variety of herbal plants as herbal medicine such as dlingo, bengle, turmeric, ginger, Intersection jokes. This herbal plant is sliced into small pieces and put into a mix together with yellow rice and coins. Herbal medicine for personal health.

\section{CONCLUSIONS}

When the Javanese were not familiar with the written tradition, all hopes or ideals were symbolically personified in the form of actions or goods. This tradition became known as local wisdom. Likewise, at the Javanese bride calling ceremony. All hopes or teachings of good are symbolized in action (ceremonial procedure) and form of goods (procedure). To interpret the teachings in the summon ceremony, cultural semantic analysis is needed. This cultural semantics is very context sensitive, namely the context of Javanese culture. The teachings contained in the ceremonies and procedures for panggih bride Yogyakarta style is the ideal of harmony in building a family.

\section{REFERENCES}

[1] S. Pringgawidagda, Pengantin Gaya Yogyakarta: Tata Upacara dan Wicara. Yogyakarta: Kanisius, 2006.

[2] S. Dwijonagoro and Suparno, "PRANATACARA LEARNING: MODELING, MIND MAPPING, E-LEARNING, OR HYBRID LEARNING?,” CAKRAWALA PENDIDIKAN, vol. 38, no. 1, 2019.

[3] Suwarna, "Makna Simbolik dalam Upacara Pengantin Jawa," Yogyakarta, 2009.

[4] S. K. Bogdan, Robert \& Biklen, Qualitative Research for Education: An Introduction to Theories and Methods. Boston: Allyn and Bacon, Inc., 2007.

[5] L. Moleong, Metodologi Penelitian Kualitatif. Bandung: PT. Remaja Rosdakarya, 2010.

[6] M. Miles and A. M. Huberman, Analisis Data Kualitatif (translated). Jakarta: UI Press, 1992. 